\title{
Adding value to ragworms (Hediste diversicolor) through the bioremediation of a super-intensive marine fish farm
}

\author{
Bruna Marques ${ }^{1}$, Ana Isabel Lillebø ${ }^{1}$, Fernando Ricardo ${ }^{1}$, Cláudia Nunes ${ }^{2,3}$, \\ Manuel A. Coimbra ${ }^{3}$, Ricardo Calado ${ }^{1, *}$
}

${ }^{1}$ Department of Biology \& CESAM \& ECOMARE, ${ }^{2}$ CICECO - Aveiro Institute of Materials, and ${ }^{3}$ Department of Chemistry \& QOPNA, University of Aveiro, Campus Universitário de Santiago, 3810-193 Aveiro, Portugal

\begin{abstract}
The aim of this study was to evaluate the potential added value of Hediste diversicolor, cultured for $5 \mathrm{mo}$ in sand bed tanks supplied with effluent water from a super-intensive marine fish farm, by comparing their fatty acid (FA) profile with that of wild specimens. The polychaetes showed an approximately 35 -fold increase in biomass during the experimental period and their FA profile was significantly different from that of wild specimens. In cultivated specimens, the most abundant FA class was that of highly unsaturated FA (HUFA), with eicosapentaenoic acid (EPA, 20:5n-3) being the best represented. Similar percentage (SIMPER) analysis showed an average $20.2 \%$ dissimilarity between the FA profile of wild and cultivated specimens, supporting the view that the culture system employed enables the recovery of high value nutrients (e.g. EPA and docosahexaenoic acid [DHA, 22:6n-3]) from fish feeds into the tissues of $H$. diversicolor that would otherwise be lost from the production environment. While the nutritional value of wild ragworms is well established in marine aquaculture (namely for broodstock maturation diets), the higher level of DHA displayed by the specimens produced under the proposed culture system may grant them a premium market value.
\end{abstract}

KEY WORDS: Integrated multi-trophic aquaculture · IMTA $\cdot$ Polychaete-assisted sand filters $\cdot$ Fatty acids

\section{INTRODUCTION}

Recirculating aquaculture systems (RAS) are currently considered one of the paradigms of the Blue Revolution, as they allow people to 'grow fish any-

${ }^{*}$ Corresponding author: rjcalado@ua.pt

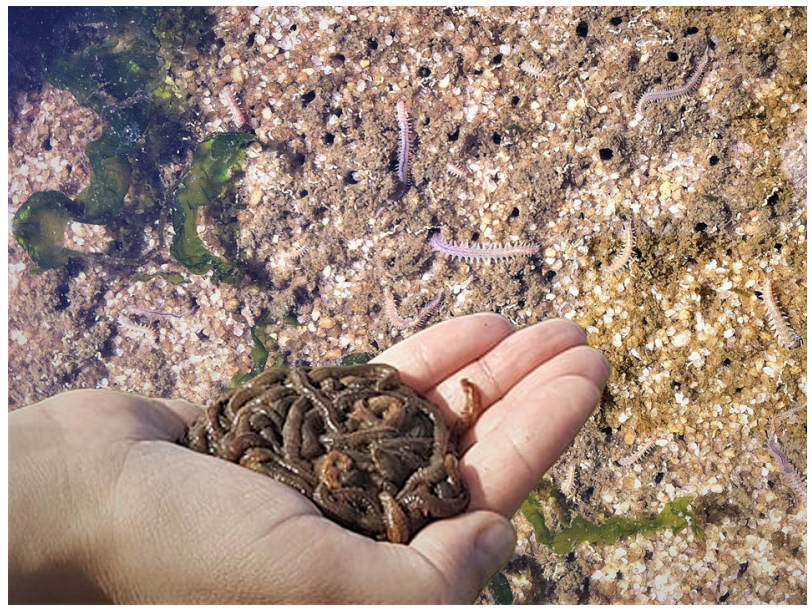

Ragworms (Hediste diversicolor) on sand filters of a superintensive brackish-water fish farm, cultured using the farm's organic-rich effluent and displaying a greater content of docosahexaenoic acid (DHA, 22:6n-3) than wild conspecifics.

Photo: Bruna Marques, Universidade de Aveiro

where' (Martins et al. 2010). The principles behind RAS promote the treatment and reuse of culture water, with $10 \%$ or less of the total water volumes having to be replaced per day (Hutchinson et al. 2004, van Rijn et al. 2006). However, one of the constraints impairing the expansion of these production systems (in a closed or semi-closed operation) is the challenge associated with the load of organic-rich suspended particulate matter (POM), dissolved organic matter (DOM) and nutrients in dissolved inorganic form (nitrogen, N, and phosphorus, P) present in its effluent (Schneider et al. 2005, Marques et al. 2017).

() The authors 2018. Open Access under Creative Commons by Attribution Licence. Use, distribution and reproduction are unrestricted. Authors and original publication must be credited. 
A number of integrated multi-trophic aquaculture (IMTA) systems have been developed in order to reduce the nutrient load present in the effluents produced when growing finfish or shrimp. In other words, IMTA combines the integrated culture of fed target species (e.g. finfish/shrimp) with that of extractive species that use particulate or dissolved organic matter (e.g. shellfish/herbivorous fish) or dissolved inorganic nutrients (e.g. seaweed/halophytes) generated through the excretion products of fed species and uneaten feed (Schneider et al. 2005, Chopin et al. 2008, Alexander et al. 2015). Overall, this environmentally friendly approach aims to address the impacts commonly associated with conventional aquaculture, such as nutrient loading and sedimentation (Schneider et al. 2005, Barrington et al. 2009). In this way, promoting IMTA practices may help to overcome the current bottlenecks faced by enterprises operating RAS, as the nutrient-rich effluents that they generate may be used to culture additional species. While on one side this approach allows the nutrient load issue to be addressed from a biomitigation perspective, through the incorporation of nutrients in extractive species biomass, it also opens up the opportunity of adding new cash-crops to the production model through the valorization of those extractive species (Chopin et al. 2008, Alexander et al. 2015).

The polychaete Hediste diversicolor (O.F. Müller, 1776), popularly known as ragworm, is a candidate species for land-based IMTA systems, as it can efficiently recycle particulate organic nutrients present in fish farm effluents (Scaps 2002, Bischoff et al. 2009, Santos et al. 2016). This polychaete is a burrowing species that inhabits the soft bottoms of shallow marine and brackish waters environments, generally in sediments with high organic contents, in the North temperate zone of European and North American Atlantic coasts (Scaps 2002, Lillebø et al. 2012). $H$. diversicolor exhibits a 'bentho-pelagic life cycle' (Scaps 2002, Nesto et al. 2012). It is one of the rare Nereid species which remain atokous throughout their lifespan, contrasting with some other Nereids which undergo a metamorphosis to a typical epitokous heteronereid form (Scaps 2002, Breton et al. 2003, Aberson et al. 2011). During reproduction, the female incubates the eggs for a period of 10 to $14 \mathrm{~d}$ inside the gallery, and dies soon afterwards. In this way, the direct or brooded larval development permits a greater flexibility in the level of development of the released offspring (Aberson et al. 2011). The feeding modes of this polychaete are diversified, ranging from surface deposit to suspension feeding, and they are also able to scavenge and actively prey on other organisms (including conspecifics) (Luis \& Passos 1995, Fidalgo e Costa et al. 2000, Bischoff et al. 2009). The interactions with its environment show an efficient adaptation to a variation of environmental parameters such as salinity, temperature and dissolved oxygen (Smith 1964, Fritzsche \& von Oertzen 1995, Murray et al. 2017). Polychaetes also play an important ecological role in the marine environment, as they are major contributors to the resuspension of organic matter via bioturbation (Würzberg et al. 2011), a feature of great relevance for their potential use in IMTA. Indeed, some studies have already highlighted how polychaetes can be successfully employed in the bioremediation of aquaculture effluents under an IMTA framework (Palmer 2010, Fang et al. 2017).

The nutritional value of ragworms is well established in marine aquaculture, with these organisms being a highly valued item in marine finfish and shrimp maturation diets (Olive 1999, Techaprempreecha et al. 2011, Santos et al. 2016). One of the main reasons for their popularity is their fatty acid (FA) profile, namely the levels they display of important polyunsaturated FA (PUFA) (Brown et al. 2011, Santos et al. 2016). Some polychaete species, including $H$. diversicolor, are able to biosynthesize PUFA, such as 20:5n-3 eicosapentaenoic acid (EPA) and 22:6n-3 docosahexaenoic acid (DHA), which are known to be essential for marine finfish and shrimp (Olive 1999, Fidalgo e Costa et al. 2000).

In order to evaluate the potential valorization of $H$. diversicolor cultured in sand bed tanks supplied with effluent water from a super-intensive marine fish farm, their fatty acid profile was determined and compared with that of wild specimens. The experimental procedure aimed to test (1) whether ragworm FA profiles depend on food source, by comparing cultured and wild specimens, and (2) whether the FA profiles of ragworms cultured in sand bed tanks supplied with RAS effluent are size-dependent, by comparing small, medium and large ragworms.

\section{MATERIALS AND METHODS}

\section{Experimental set-up}

Effluent originating from a super intensive RAS system farming Senegalese sole Solea senegalensis was pumped from a settling basin to a bio-block tower system, in order to allow the effluent water to trickle and increase its oxygen levels before reaching 
the header tank reservoir. In this header tank, the effluent was strongly aerated and set to flow in parallel into 6 experimental sand bed tanks. Each of these tanks had an approximate volume of $1 \mathrm{~m}^{3}$ and a surface area of $1 \mathrm{~m}^{2}$. The bottom of each tank was covered by $200 \mathrm{~mm}$ of sand (1 to $2 \mathrm{~mm}$ grain size substratum) beneath which a draining pipe allowed the effluent water to percolate through the sand bed. Each tank was equipped with 2 outlets, one that regulated the water level inside the tank and allowed the water to drain and another one that was set to prevent the tank from overflowing in case the sand bed became clogged and impaired water percolation. Sand bed tanks were placed in parallel and supplied with aerated RAS effluent water by gravity at a flow of $180 \mathrm{l} \mathrm{h}^{-1}$. All tanks were equipped with a $0.8 \mathrm{~m}$ diameter ring of aeration hose supplying compressed air (see Marques et al. 2017). Three of the 6 experimental sand bed tanks were stocked with wild polychaetes (WP), while the remaining 3 were set as controls. The experiment was run for 5 mo (from May to October) and no additional feed was provided to the polychaetes during this period to supplement the organic-rich effluent containing uneaten/undigested feed and fish feces. During the experimental period, temperature, salinity, $\mathrm{pH}$ and dissolved oxygen concentration of the effluent water being supplied to the tanks was monitored twice a month using a WTW Cond 3110/SET 1 equipped with TetraCon ${ }^{\circledR}$ 325, a WTW pH 330i/SET equipped with SenTix ${ }^{\circledR} 41$, and a WTW Oxi 3210/SET 2 equipped with CellOx ${ }^{\circledR}$ 325-3, respectively.

\section{Polychaete stocking and sampling}

Wild specimens of Hediste diversicolor (average total length between 80 and $100 \mathrm{~mm}$, the commercial size of this species when traded as bait for sports fishing) were collected in the Ria de Aveiro coastal lagoon (Portugal 40³8' 04.8" N, 8³9'52.4" W) by local fishermen, and 200 individuals (with a combined weight of $130 \mathrm{~g}$ ) were stocked in each of the 3 sand bed tanks randomly selected to act as polychaete-assisted sand filters. At 5 mo post-stocking, polychaetes were sampled using a hand corer (110 mm diameter and $150 \mathrm{~mm}$ long), with 3 cores being taken from each colonized sand bed tank. Polychaete specimens were sorted in situ and transported to the laboratory in sterilized sand and clean seawater. At the laboratory, all specimens were left to depurate overnight in pre-combusted sand and artificial seawater prepared to match salinity in situ
(20). Subsequently, all sampled specimens were separated into 3 pre-established size classes (small $<30 \mathrm{~mm}$, medium 30 to $50 \mathrm{~mm}$ and large $>50 \mathrm{~mm}$ ). At the beginning of the experiment, triplicate samples of WP (all from the large class) that were used to stock the tanks, were left to depurate overnight under identical conditions as those previously described. After depuration, wild polychaetes and those originating from the sand bed tanks were freeze-dried and stored at $-80^{\circ} \mathrm{C}$ for subsequent FA analysis.

\section{Sampling of potential nutrient sources of POM for FA analysis}

To perform the FA characterization of all potential nutrient sources available to the ragworms stocked in the sand bed tanks, triplicate samples of the 2 fish feed types (FEED A and B) used during the grow-out of $S$. senegalensis in the RAS system, as well as uneaten/undigested feed and fish feces accumulated in the cyclone filters (POM), were collected, freeze dried and stored at $-80^{\circ} \mathrm{C}$ for posterior FA analysis. The top $10 \mathrm{~mm}$ of the sand bed surface of each tank stocked with ragworms, all organic-rich settled particles (OM), were also collected in triplicate from each tank and were also processed as described above for FA analysis.

\section{FA extraction and analysis}

The derivation of FAs for gas chromatography (GC) analysis was performed following the methodology described by Aued-Pimentel et al. (2004), adjusting the weight, as this method has the advantage of being performed at room temperature and thus reducing the risks of FA decomposition. All freeze-dried samples were powdered and homogenized, weighed accurately in a Sovirel Pyrex glass tube (40 mg of ragworm biomass, $20 \mathrm{mg}$ of FEED, $40 \mathrm{mg}$ of POM and $150 \mathrm{mg}$ of $\mathrm{OM}$ ) and dissolved in $1 \mathrm{ml}$ of the internal standard solution of a methyl ester fatty acid C21:0 in $n$-hexane $\left(0.35 \mathrm{~g} \mathrm{l}^{-1}\right)$. In the same tube, $0.2 \mathrm{ml}$ of a methalonic $\mathrm{KOH}$ solution $\left(2 \mathrm{~mol} \mathrm{l}^{-1}\right)$ was added, and the tube was sealed and mixed vigorously in a vortex shaker for $30 \mathrm{~s}$. Following this procedure, $2 \mathrm{ml}$ of a saturated $\mathrm{NaCl}$ solution was added to the tube, and the mixture was centrifuged for $5 \mathrm{~min}$ at $1409 \times g$. The separated organic phase $(1 \mathrm{ml})$ was transferred into another tube and the excess solvent was removed under vacuum. The oil obtained was dissolved in $n$ hexane $(200 \mu \mathrm{l})$ and analyzed by gas chromatography 
with a flame ionization detector (GC-FID), using a Perkin Elmer 400 instrument (PerkinElmer). The detector and injector were kept at $250^{\circ} \mathrm{C}$, with hydrogen as carrier gas. FAs were separated in a fused-silica capillary column, DB-FFAP (30 m length, $0.32 \mathrm{~mm}$ internal diameter, $0.25 \mu \mathrm{m}$ film thickness, J \& W Scientifics) with the following temperature program: $50^{\circ} \mathrm{C}$ for $3 \mathrm{~min}, 40^{\circ} \mathrm{C} \mathrm{m^{-1 }}$ to $160^{\circ} \mathrm{C}, 2^{\circ} \mathrm{C} \mathrm{min}^{-1}$ to $210^{\circ} \mathrm{C}$, $20^{\circ} \mathrm{C} \mathrm{min}^{-1}$ to $250^{\circ} \mathrm{C}$ (for $1 \mathrm{~min}$ ). The identification of FAs was done by matching with a previously injected standards mixture (Supelco ${ }^{\circledR} 37$ component FAME mix, Sigma-Aldrich). The FA content ( $\mu \mathrm{g} \mathrm{mg}^{-1}$ dry weight, DW) in the samples analyzed was calculated considering the relationship between mass, the area of FAs and the internal standard (C21:0). PUFA are defined as all FA with $\geq 2$ double bonds; in the present study, highly unsaturated fatty acids (HUFA, FAs with $\geq 4$ double bonds) are considered separately.

\section{Statistical analysis}

Statistical analysis was performed using PRIMER v6 with the PERMANOVA+ add-on. A resemblance matrix using the content ( $\mu \mathrm{g} \mathrm{g} \mathrm{g}^{-1} \mathrm{DW}$ ) of each FA in each sample was prepared using the Bray-Curtis similarity coefficient, after performing a $\log (x+1)$ transformation to emphasize compositional rather than quantitative differences (Anderson 2008). Hypotheses were tested by performing 2 independent 1 -way analyses of similarities (ANOSIM). To assess the differences between FA profiles of cultured polychaetes versus WP and those of small, medium and large cultured polychaetes (SPC, MPC and $\mathrm{LPC}$, respectively) in sand bed tanks, a global $\mathrm{R}$ statistic was calculated where values close to 1 indicate maximum differences between groups and values near 0 indicate a complete group overlay. Similarity percentage (SIMPER) analysis was also performed to evaluate the percentage that each FA contributed to the dissimilarity recorded between samples, with those contributing $50 \%$ of cumulative dissimilarities being highlighted. Hierarchical cluster analysis was performed to group the samples according to their similarity. A dendrogram was used to highlight the hierarchical similarity among the samples. Similarity among the samples was calculated using the BrayCurtis similarity measure and the group average algorithm was used to group the samples successively in a hierarchical way. A canonical analysis of principal coordinates (CAP) was performed to evaluate the strongest correlation of LPC in the predefined groups (OM, POM, FEED A and B). For a detailed description of all the statistical analysis described above please refer to Clarke \& Gorley (2006).

\section{RESULTS}

\section{Biomass production of ragworms}

During the 5 mo experimental period, water parameters (average \pm standard deviation, SD) within the sand bed tanks remained stable (see Table A1 in the Appendix), with an average water temperature of $19.6 \pm 1.3^{\circ} \mathrm{C}$, salinity $21.2 \pm 0.2, \mathrm{pH} 7.8 \pm 0.2$ and dissolved oxygen $8.4 \pm 0.7 \mathrm{mg} \mathrm{l}^{-1}$.

The final average $( \pm \mathrm{SD})$ weight of cultured polychaete biomass was $2622 \pm 869 \mathrm{~g}$, corresponding to $104 \pm 68,226 \pm 137$ and $2292 \pm 664 \mathrm{~g}$ for SPC, MPC and LPC, respectively. During this period, polychaete density increased from 200 individuals (ind.) $\mathrm{m}^{-2}$ to up to 7094 ind. $\mathrm{m}^{-2}$, which represented an approximately 35 -fold increase in density, solely considering LPC (initial biomass of $130 \mathrm{~g}$ increasing to $2292 \mathrm{~g} 5$ mo later) and approximately 18 -fold considering the whole biomass of cultured polychaetes (initial biomass of $130 \mathrm{~g}$ increasing to $2622 \mathrm{~g} 5$ mo later).

On average, the total numbers of polychaetes per tank were $9608 \pm 5922,3374 \pm 1464$ and $7094 \pm$ 1375 ind. $\mathrm{m}^{-2}$, for SPC, MPC and LPC, respectively. The average number of LPC recorded represented approximately 100 bait packages similar to those originally introduced into the system (each pack of bait holds $\sim 70$ individuals).

\section{FA profile analysis}

The FA profiles of WP, SPC, MPC and LPC (these displaying a similar size to that of wild specimens), POM, OM, and FEED A and B are summarized in Table 1. Considering FA classes, WP and LPC displayed similar profiles; however, the ANOSIM test revealed the existence of significant differences $(R=$ $1, p=0.002$ ) between the FA profiles of WP and LPC. HUFA was the most abundant FA class $(8.78 \pm 0.70$ and $14.23 \pm 1.08 \mathrm{\mu g} \mathrm{g}^{-1} \mathrm{DW}$ for WP and LPC, respectively), with EPA (20:5n-3) being the best represented FA $\left(5.51 \pm 0.29\right.$ and $8.34 \pm 0.36 \mu \mathrm{g} \mathrm{g}^{-1} \mathrm{DW}$ for WP and LPC, respectively). PUFA averaged $2.34 \pm 0.38$ and $3.99 \pm 0.46 \mu \mathrm{g} \mathrm{g}^{-1} \mathrm{DW}$ for WP and LPC, respectively, while monounsaturated fatty acids (MUFA) averaged $6.69 \pm 1.28$ and $10.05 \pm 1.08 \mu g^{-1}$ DW for WP and LPC, respectively. Concerning saturated fatty acids 
Table 1. Fatty acid (FA) profiles ( $\mu \mathrm{g} \mathrm{g}^{-1} \mathrm{DW}$ ) of wild (WP), and small, medium and large Hediste diversicolor cultured in the sand bed tanks (SPC, MPC and LPC, respectively), organic matter (OM), particulate organic matter (POM) and fish feed (FEED A and FEED B). Values are averages of 9, 6 or 3 replicates \pm standard deviation. ND: fatty acid not detected. SFA: saturated fatty acids $(14: 0 ; 15: 0 ; 16: 0 ; 17: 0 ; 18: 0 ; 20: 0)$; MUFA: monounsaturated fatty acids $(16: 1 n-7 ; 16: 1 n-9 ; 18: 1 n-9 ; 18: 1 n-7$; $18: 1 n-5 ; 20: 1 n-9 ; 22: 1 n-9)$; PUFA: polyunsaturated fatty acids $(16: 2 n-6 ; 18: 2 n-6 ; 18: 2 n-3 ; 18: 3 n-6 ; 18: 3 n-3 ; 20: 2 n-6 ; 20: 2 n-9$; 20:3n-6); HUFA: highly unsaturated fatty acids (20:4n-6 [arachidonic acid, AA]; 20:5n-3 [eicosapentaenoric acid, EPA]; 22:4n$6 ; 22: 5 n-3 ; 22: 6 n-3$ [docosahexaenoic acid, DHA]). PUFA are defined as all FA with $\geq 2$ double bonds; in the present study, HUFA (FA with $\geq 4$ double bonds) are not considered within $\sum$ PUFA. Others refers to the FAs 14:0 (iso), 15:0 (iso) and 16:0 (iso)

\begin{tabular}{|c|c|c|c|c|c|c|c|c|}
\hline FA & $\begin{array}{c}\text { WP } \\
(\mathrm{n}=9)\end{array}$ & $\begin{array}{c}\text { SPC } \\
(n=9)\end{array}$ & $\begin{array}{l}\text { MPC } \\
(n=9)\end{array}$ & $\begin{array}{c}\text { LPC } \\
(n=9)\end{array}$ & $\begin{array}{c}\text { OM } \\
(\mathrm{n}=9)\end{array}$ & $\begin{array}{l}\text { POM } \\
(\mathrm{n}=6)\end{array}$ & $\begin{array}{c}\text { FEED A } \\
(\mathrm{n}=3)\end{array}$ & $\begin{array}{c}\text { FEED B } \\
(\mathrm{n}=3)\end{array}$ \\
\hline $14: 0$ & $0.10 \pm 0.03$ & $0.22 \pm 0.03$ & $0.25 \pm 0.04$ & $0.33 \pm 0.05$ & $0.36 \pm 0.03$ & $2.39 \pm 0.37$ & $4.09 \pm 0.44$ & $8.18 \pm 0.63$ \\
\hline $15: 0$ & $0.27 \pm 0.05$ & $0.23 \pm 0.03$ & $0.21 \pm 0.03$ & $0.28 \pm 0.03$ & $0.06 \pm 0.01$ & $0.22 \pm 0.03$ & ND & ND \\
\hline $16: 0$ & $4.22 \pm 1.10$ & $3.53 \pm 0.28$ & $3.66 \pm 0.57$ & $5.63 \pm 0.85$ & $1.31 \pm 0.22$ & $8.16 \pm 1.16$ & $13.53 \pm 1.33$ & $23.44 \pm 1.22$ \\
\hline $17: 0$ & $0.27 \pm 0.06$ & $0.34 \pm 0.03$ & $0.34 \pm 0.02$ & $0.46 \pm 0.07$ & ND & $0.35 \pm 0.09$ & $0.60 \pm 0.06$ & $1.48 \pm 0.21$ \\
\hline $18: 0$ & $1.65 \pm 0.37$ & $1.56 \pm 0.19$ & $1.64 \pm 0.13$ & $2.28 \pm 0.16$ & $0.34 \pm 0.06$ & $1.87 \pm 0.23$ & $0.61 \pm 0.03$ & $3.39 \pm 1.21$ \\
\hline$\sum \mathrm{SFA}$ & $6.52 \pm 1.62$ & $5.89 \pm 0.55$ & $6.10 \pm 0.79$ & $8.99 \pm 1.16$ & $2.14 \pm 0.36$ & $13.16 \pm 1.89$ & $18.83 \pm 1.86$ & $36.50 \pm 3.27$ \\
\hline $16: 1 n-7$ & $0.27 \pm 0.06$ & $0.57 \pm 0.08$ & $0.63 \pm 0.07$ & $0.90 \pm 0.13$ & $0.14 \pm 0.20$ & $2.38 \pm 0.40$ & ND & ND \\
\hline $16: 1 n-9$ & ND & ND & ND & ND & $0.86 \pm 0.16$ & ND & $4.66 \pm 0.44$ & $9.09 \pm 0.76$ \\
\hline $18: 1 n-9$ & $1.96 \pm 0.43$ & $1.83 \pm 0.22$ & $1.96 \pm 0.06$ & $2.39 \pm 0.19$ & $0.48 \pm 0.08$ & $7.77 \pm 1.95$ & $2.97 \pm 0.31$ & $9.64 \pm 5.07$ \\
\hline $18: 1 n-7$ & $0.31 \pm 0.05$ & $0.77 \pm 0.06$ & $0.89 \pm 0.20$ & $1.39 \pm 0.20$ & $0.58 \pm 0.10$ & $1.53 \pm 0.63$ & $25.13 \pm 3.17$ & $5.98 \pm 4.13$ \\
\hline $18: 1 n-5$ & $1.74 \pm 0.44$ & $1.49 \pm 0.20$ & $1.43 \pm 0.11$ & $1.87 \pm 0.22$ & ND & ND & ND & ND \\
\hline $20: 1 n-9$ & $1.86 \pm 0.22$ & $2.14 \pm 0.24$ & $2.27 \pm 0.17$ & $2.80 \pm 0.20$ & $0.14 \pm 0.18$ & $0.86 \pm 0.17$ & $2.71 \pm 0.25$ & $1.99 \pm 0.10$ \\
\hline $22: 1 n-9$ & $0.54 \pm 0.08$ & $0.48 \pm 0.09$ & $1.00 \pm 0.12$ & $0.71 \pm 0.11$ & $0.05 \pm 0.02$ & $1.64 \pm 0.60$ & $2.00 \pm 0.21$ & $2.11 \pm 0.19$ \\
\hline$\Sigma$ MUFA & $6.69 \pm 1.28$ & $7.28 \pm 0.90$ & $8.18 \pm 0.73$ & $10.05 \pm 1.08$ & $2.26 \pm 0.74$ & $14.17 \pm 3.74$ & $37.47 \pm 4.38$ & $28.81 \pm 10.25$ \\
\hline $18: 2 n-6$ & $0.22 \pm 0.03$ & $0.56 \pm 0.08$ & $0.72 \pm 0.16$ & $1.13 \pm 0.09$ & $0.16 \pm 0.03$ & $4.31 \pm 1.10$ & $9.68 \pm 1.13$ & $5.31 \pm 0.40$ \\
\hline $18: 3 n-6$ & $1.12 \pm 0.15$ & $0.14 \pm 0.05$ & $0.17 \pm 0.01$ & $0.32 \pm 0.04$ & $0.09 \pm 0.02$ & $0.65 \pm 0.20$ & $2.75 \pm 0.26$ & $1.62 \pm 0.12$ \\
\hline $18: 3 n-3$ & $0.49 \pm 0.10$ & ND & ND & ND & ND & $0.29 \pm 0.10$ & ND & ND \\
\hline $20: 2 n-6$ & $0.25 \pm 0.05$ & $0.49 \pm 0.05$ & $0.56 \pm 0.09$ & $1.08 \pm 0.24$ & $2.29 \pm 0.20$ & ND & $0.18 \pm 0.31$ & $0.11 \pm 0.08$ \\
\hline$\Sigma$ PUFA & $2.34 \pm 0.38$ & $2.08 \pm 0.33$ & $1.89 \pm 0.33$ & $3.99 \pm 0.46$ & $2.55 \pm 0.25$ & $5.26 \pm 1.40$ & $14.53 \pm 1.86$ & $10.79 \pm 1.16$ \\
\hline $20: 4 n-6$ (AA) & $0.84 \pm 0.10$ & $0.99 \pm 0.33$ & $1.25 \pm 0.15$ & $1.61 \pm 0.17$ & $0.12 \pm 0.02$ & $0.15 \pm 0.04$ & $0.74 \pm 0.13$ & $1.10 \pm 0.04$ \\
\hline 20:5n-3 (EPA) & $5.51 \pm 0.29$ & $5.65 \pm 0.62$ & $6.43 \pm 0.51$ & $8.34 \pm 0.36$ & $0.36 \pm 0.12$ & $0.11 \pm 0.04$ & $7.06 \pm 0.71$ & $16.20 \pm 2.15$ \\
\hline $22: 4 n-6$ & $0.39 \pm 0.19$ & $1.13 \pm 0.26$ & $1.24 \pm 0.04$ & $1.75 \pm 0.23$ & ND & $0.31 \pm 0.07$ & $0.17 \pm 0.02$ & $0.31 \pm 0.02$ \\
\hline $22: 5 n-3$ & $2.03 \pm 0.12$ & $1.25 \pm 0.16$ & $1.37 \pm 0.17$ & $1.72 \pm 0.18$ & $0.04 \pm 0.01$ & $0.22 \pm 0.09$ & $1.25 \pm 0.16$ & $1.32 \pm 0.21$ \\
\hline $22: 6 n-3$ (DHA) & ND & $0.60 \pm 0.19$ & $0.49 \pm 0.07$ & $0.82 \pm 0.14$ & $0.37 \pm 0.06$ & $1.73 \pm 0.58$ & $8.25 \pm 0.75$ & $10.61 \pm 1.29$ \\
\hline$\sum$ HUFA & $8.78 \pm 0.70$ & $9.62 \pm 1.56$ & $10.79 \pm 0.92$ & $14.23 \pm 1.08$ & $0.89 \pm 0.21$ & $2.52 \pm 0.83$ & $17.48 \pm 1.77$ & $29.54 \pm 3.70$ \\
\hline EOthers & $0.09 \pm 0.00$ & $0.51 \pm 0.10$ & $0.43 \pm 0.08$ & $0.38 \pm 0.08$ & $0.21 \pm 0.11$ & $0.22 \pm 0.02$ & ND & ND \\
\hline
\end{tabular}

(SFA), WP presented $6.52 \pm 1.62 \mu \mathrm{g} \mathrm{g} \mathrm{g}^{-1} \mathrm{DW}$, while LPC displayed $8.99 \pm 1.16 \mu \mathrm{g} \mathrm{g}^{-1} \mathrm{DW}$, with the most representative SFA being palmitic acid (16:0) $(4.22 \pm 1.10$ and $5.63 \pm 0.85 \mathrm{\mu g} \mathrm{g}^{-1} \mathrm{DW}$ for WP and LPC, respectively). The identification and quantification of the FA profiles of FEED A and B, POM and OM revealed that the most representative FA in each of these samples was: (MUFA) vaccenic acid $(18: 1 n-7)(25.13 \pm 3.17 \mu \mathrm{g}$ $\mathrm{g}^{-1} \mathrm{DW}$ ) for FEED $\mathrm{A}_{i}$ (SFA) palmitic acid (16:0) for FEED B $\left(23.44 \pm 1.22 \mu \mathrm{g} \mathrm{g}^{-1} \mathrm{DW}\right)$ and POM $(8.16 \pm$ $1.16 \mathrm{\mu g} \mathrm{g}^{-1}$ DW), and (PUFA) eicosadienoic acid $(\mathrm{C} 20: 2 n-6)\left(2.29 \pm 0.20 \mathrm{\mu g} \mathrm{g}^{-1} \mathrm{DW}\right)$ for OM.

SIMPER analysis showed that the FA profiles of WP and LPC displayed an average dissimilarity of $20.2 \%$, with more than $50 \%$ of that dissimilarity being explained by the following FAs: 18:3n-3 (alphalinolenic acid, ALA), 22:4n-6 (docosatetraenoic acid, DTA), 18:2n-6 (linoleic acid), 22:6n-3 (DHA), 18:1n-9 (oleic acid), 18:3n-6 (gamma linolenic acid, GLA) and 22:1n-9 (erucic acid) (Table 2).

The ANOSIM test revealed the existence of significant differences between the FA profiles of SPC and LPC $(\mathrm{R}=0.474, \mathrm{p}=0.011)$, and MPC and LPC $(\mathrm{R}=$ $0.319, \mathrm{p}=0.017$ ). However, the low R-values displayed in both comparisons suggest that these differences were more likely due to natural variability than promoted by the different size of the polychaetes. No significant differences were recorded in the FA profiles of SPC vs. MPC $(R=0.131, p=0.121)$. SIMPER analysis (Table 2 ) revealed that the average dissimi- 
Table 2. SIMPER overall average dissimilarities (\%) between the mean fatty acid (FA) profiles of wild (WP), and small, medium and large (SPC, MPC and LPC, respectively) Hediste diversicolor cultured in the sand bed tanks, and organic matter $(\mathrm{OM})$, particulate organic matter (POM) and fish feed (FEED A and FEED B)

\begin{tabular}{|c|c|c|c|c|c|c|c|c|c|c|c|}
\hline \multicolumn{3}{|c|}{$\mathrm{W} \& \mathrm{LPC}$} & \multicolumn{3}{|c|}{ SPC \& LPC } & \multicolumn{3}{|c|}{ MPC \& LPC } & \multicolumn{3}{|c|}{$\mathrm{SPC} \& \mathrm{MPC}$} \\
\hline FA & $\begin{array}{c}\text { Contrib. } \\
\%\end{array}$ & $\underset{\%}{\text { Cum. }}$ & FA & $\begin{array}{c}\text { Contrib. } \\
\%\end{array}$ & $\underset{\%}{\text { Cum. }}$ & FA & $\begin{array}{c}\text { Contrib. } \\
\%\end{array}$ & $\underset{\%}{\text { Cum. }}$ & FA & $\begin{array}{c}\text { Contrib. } \\
\%\end{array}$ & $\underset{\%}{\mathrm{Cum} .}$ \\
\hline $18: 3 n-3$ & 8.98 & 8.98 & $18: 2 n-6$ & 9.53 & 9.53 & $16: 0$ & 8.87 & 8.87 & $20: 4 n-6$ & 10.76 & 10.76 \\
\hline $22: 4 n-6$ & 8.54 & 17.53 & $22: 5 n-3$ & 8.52 & 18.05 & $18: 2 n-6$ & 8.24 & 17.11 & $20: 5 n-3$ & 8.22 & 18.98 \\
\hline $18: 2 n-6$ & 8.30 & 25.83 & $20: 4 n-6$ & 7.73 & 25.78 & $20: 5 n-3$ & 7.67 & 24.79 & 16:0 & 7.31 & 26.29 \\
\hline $22: 6 n-3$ & 8.08 & 33.91 & $22: 1 n-9$ & 7.41 & 33.19 & $22: 1 n-9$ & 6.79 & 31.57 & $22: 4 n-6$ & 6.93 & 33.23 \\
\hline $18: 1 n-9$ & 7.70 & 41.61 & $16: 0$ & 7.30 & 40.49 & $20: 2 n-6$ & 6.76 & 38.34 & $22: 6 n-3$ & 6.78 & 40.01 \\
\hline \multirow{2}{*}{$\begin{array}{l}18: 3 n-6 \\
22: 1 n-9\end{array}$} & 6.85 & 48.46 & $20: 2 n-6$ & 6.58 & 47.07 & $18: 1 n-9$ & 6.63 & 44.97 & $18: 2 n-6$ & 6.61 & 46.62 \\
\hline & 6.51 & 54.97 & $18: 1 n-9$ & 6.18 & 53.25 & $18: 0$ & 5.68 & 50.65 & $18: 1 n-9$ & 5.90 & 52.53 \\
\hline \multicolumn{3}{|c|}{ FEED A \& LPC } & \multicolumn{3}{|c|}{ FEED B \& LPC } & \multicolumn{3}{|c|}{ POM \& LPC } & \multicolumn{3}{|c|}{ OM \& LPC } \\
\hline FA & $\begin{array}{c}\text { Contrib. } \\
\%\end{array}$ & $\underset{\%}{\text { Cum. }}$ & FA & $\begin{array}{c}\text { Contrib. } \\
\%\end{array}$ & $\underset{\%}{\text { Cum. }}$ & FA & $\begin{array}{c}\text { Contrib. } \\
\%\end{array}$ & $\underset{\%}{\text { Cum. }}$ & FA & $\begin{array}{c}\text { Contrib. } \\
\%\end{array}$ & $\underset{\%}{\text { Cum. }}$ \\
\hline $18: 1 n-9$ & 14.48 & 14.48 & $16: 1 n-9$ & 11.87 & 11.87 & $20: 5 n-3$ & 15.74 & 15.74 & $20: 5 n-3$ & 13.72 & 13.72 \\
\hline $22: 6 n-3$ & 10.01 & 24.50 & $14: 0$ & 10.21 & 2208 & $18: 1 n-11$ & 8.25 & 23.99 & $20: 1 n-9$ & 8.39 & 22.10 \\
\hline $16: 1 n-9$ & 9.86 & 34.36 & $20: 2 n-6$ & 10.18 & 32.27 & $14: 0$ & 7.91 & 31.90 & $18: 1 n-7$ & 6.77 & 28.87 \\
\hline $18: 2 n-6$ & 9.62 & 43.98 & $16: 0$ & 7.99 & 40.25 & $18: 2 n-6$ & 7.76 & 39.66 & $16: 0$ & 6.32 & 35.19 \\
\hline \multirow[t]{3}{*}{$14: 0$} & 7.95 & 51.93 & $18: 2 n-6$ & 6.00 & 46.25 & $18: 1 n-7$ & 6.95 & 46.62 & $22: 4 n-6$ & 6.31 & 41.50 \\
\hline & & & $18: 1 n-11$ & 5.90 & 52.15 & $16: 1 n-7$ & 5.71 & 52.52 & $22: 5 n-3$ & 6.23 & 47.74 \\
\hline & & & & & & & & & $22: 1 n-9$ & 5.89 & 53.63 \\
\hline
\end{tabular}

larities recorded between the FA profiles of SPC, MPC and LPC in sand bed tanks were as follows: $6.1 \%$ for LPC vs. MPC $; 8.2 \%$ for LPC vs. SPC and $5.7 \%$ for MPC vs. SPC. The single FAs contributing the most to the recorded dissimilarities were: 16:0 (explaining $8.9 \%$ of the dissimilarity between LPC and MPC); $18: 2 n-6$ (explaining $9.5 \%$ of the dissimi-

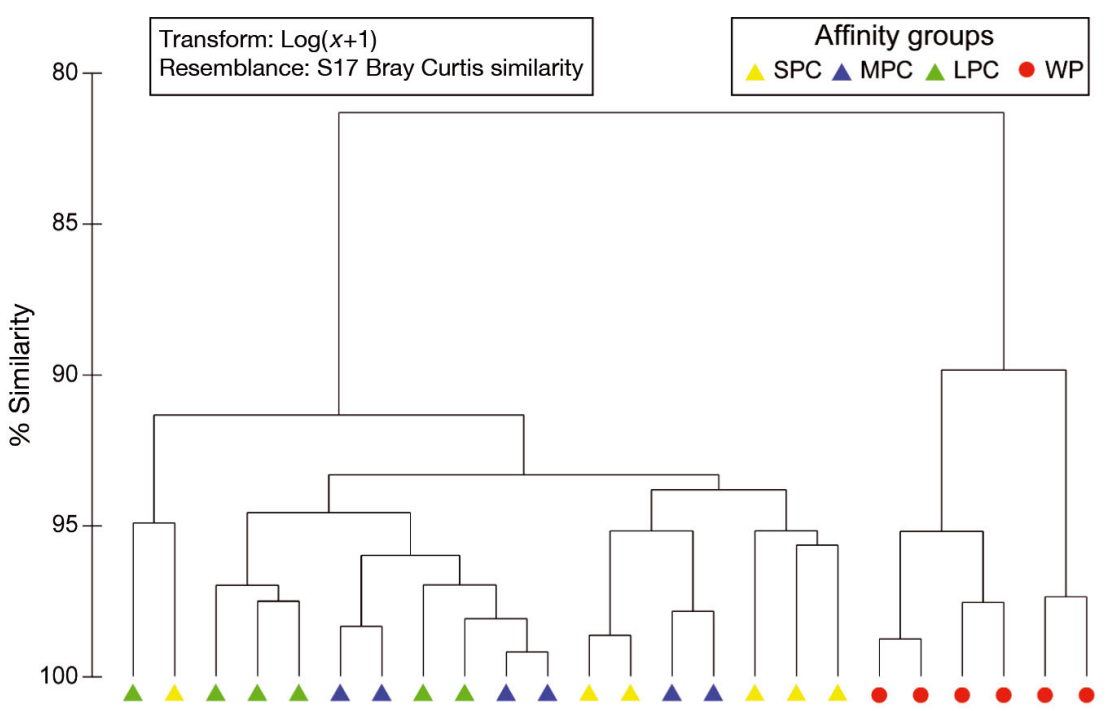

Fig. 1. Hierarchical cluster analysis groups of the fatty acid profiles of wild (WP), and small, medium and large cultured Hediste diversicolor (SPC, MPC and $\mathrm{LPC}$, respectively) larity between LPC and SPC); and 20:4n-6 (explaining $10.8 \%$ of the dissimilarity between MPC and SPC).

Regarding the FA profiles of LPC and potential sources of food (POM, OM, FEED A and B), SIMPER revealed a dissimilarity of $40.9 \%$ between LPC and POM, $60.8 \%$ between LPC and OM, and 43.7 and $44.3 \%$ between LPC and FEED A and $\mathrm{B}$, respectively (Table 2).

A first hierarchical cluster analysis (Fig. 1) revealed 2 distinct clusters (with a $90 \%$ similarity) separating the FA profiles of WP Hediste diversicolor from those of conspecifics cultured in sand bed tanks. A second hierarchical cluster analysis (Fig. 2) showed that the FA profiles displayed by OM samples were clearly separated (similarity $<60 \%$ ) from those exhibited by cultured, large $H$. diversicolor and POM, as well as FEED A and B.

The CAP analysis revealed that the FA profile most closely resembling that of LPC was that of POM, as $100 \%$ of all LPC profiles were allocated to POM when LPC was selected for the 'leave-one-out' allocation routine (Table 3). 


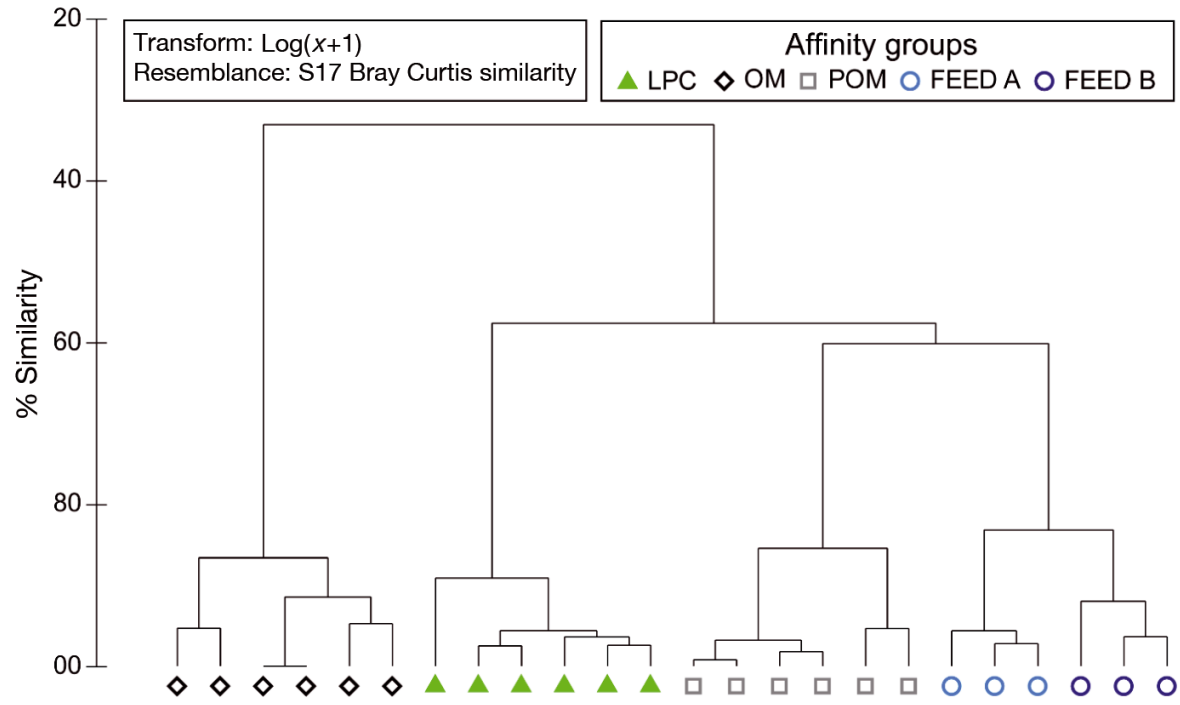

Fig. 2. Hierarchical cluster analysis groups of the fatty acid profiles of large Hediste diversicolor (LPC) cultured in the sand bed tanks, organic matter (OM), particulate organic matter (POM) and fish feed (FEED A and FEED B)

\section{DISCUSSION}

The reproduction success of wild Hediste diversicolor under cultivated conditions (i.e. using RAS effluents displaying a high level of uneaten/undigested feed and fish feces) confirms the ability of this species to switch its feeding behavior according to trophic/ environmental conditions (Bischoff et al. 2009). In fact, it has been demonstrated that under nutrientenrichment conditions, the surface deposit-feeding behavior of $H$. diversicolor is enhanced over suspension feeding and/or predation (Aberson et al. 2016). The increment recorded in biomass and density during the experimental period corroborates that the available food was sufficient to secure growth and reproduction. In addition, the bentho-pelagic life cycle of $H$. diversicolor and its direct development in the sand bed tank environment, without loss of offspring, allows reproductive success and a significant increase in polychaete density.
The FA profiles of cultivated specimens (SPC, MPC and LPC) and wild polychaetes (WP) are in agreement with previous studies (Table 4) reporting that the most abundant FA recorded in cultured and wild polychaetes are palmitic acid, stearic acid, oleic acid and EPA (García-Alonso et al. 2008, Bischoff et al. 2009, Techaprempreecha et al. 2011, Lillebø et al. 2012). Of these, EPA $\left(8.34 \pm 0.36 \mu^{-1} g^{-1}\right.$ DW in LPC

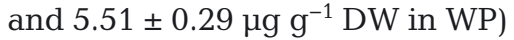
was the most abundant HUFA present in polychaete biomass. It can be seen that cultivated specimens are able to incorporate almost all available EPA in their food sources into their tissues, even when this FA is present in low levels (e.g. $0.11 \pm 0.04 \mu \mathrm{g} \mathrm{g}^{-1} \mathrm{DW}$ for POM, $0.36 \pm$ $0.12 \mu \mathrm{g} \mathrm{g}^{-1} \mathrm{DW}$ for $\mathrm{OM}, 7.06 \pm 0.71 \mu \mathrm{g} \mathrm{g}^{-1} \mathrm{DW}$ for FEED A and $16.20 \pm 2.15 \mu \mathrm{g} \mathrm{g}{ }^{-1} \mathrm{DW}$ for FEED B). EPA levels present in food sources can be complemented by the polychaetes through de novo synthesis (Santos et al. 2016). This FA is one of the major components of fish oil, a precursor of prostaglandins and thromboxane. It cannot be synthesized de novo in humans (García-Alonso et al. 2008), and is therefore classified as an essential FA (Olive 1999). DHA is also an essential FA of great importance in marine fish nutrition. The significant increase in DHA concentrations in cultured specimens may be due to a selective retention in tissues and/or their ability to elongate FAs through a pathway that involves chain elongation of EPA and its desaturation to obtain DHA (Olive et al. 2009). The absence of DHA in the tissues of wild specimens might reflect a deficiency of this FA in natural intertidal mud-flat food sources. Arachidonic acid (AA, 20:4n-6) is another $n$-6 long-chain FA es-

Table 3. Cross validation success of large Hediste diversicolor (LPC) fatty acid (FA) profile based on FA profiles of organic matter (OM), particulate organic matter (POM) and fish feed (FEED A and FEED B)

\begin{tabular}{|c|c|c|c|c|c|c|}
\hline & \multirow{2}{*}{$\overline{\mathrm{OM}}$} & \multicolumn{3}{|c|}{ Allocation of observations to groups } & \multirow[t]{2}{*}{ Total per group } & \multirow[t]{2}{*}{$\%$ correct } \\
\hline & & POM & FEED A & FEED B & & \\
\hline OM & 6 & 0 & 0 & 0 & 6 & 100 \\
\hline POM & 0 & 6 & 0 & 0 & 6 & 100 \\
\hline FEED A & 0 & 0 & 3 & 0 & 3 & 100 \\
\hline FEED B & 0 & 0 & 0 & 3 & 3 & 100 \\
\hline LPC & 0 & 6 & 0 & 0 & 6 & 100 \\
\hline
\end{tabular}




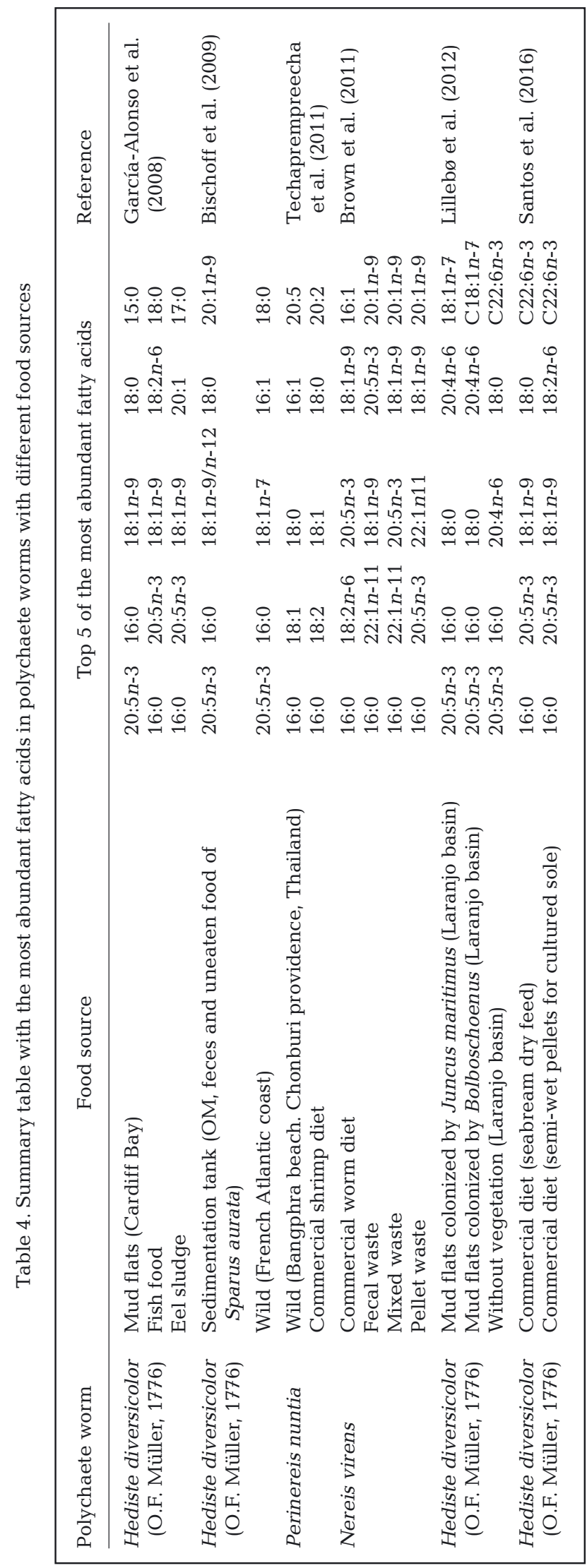

sential to fish diets. AA was detected in all samples of polychaetes (WP, SPC, MPC and LPC with $0.84 \pm$ $0.10,0.99 \pm 0.33,1.25 \pm 0.15$ and $1.61 \pm 0.17 \mu g^{-1}$ DW, respectively) and takes part in several metabolic pathways in invertebrates, e.g. Perinereis nuntia (Techaprempreecha et al. 2011) and Nereis virens (Brown et al. 2011). This FA can also be biosynthesized from linoleic acid (Bischoff et al. 2009). It has been shown that, to some extent, polychaetes (Arenicola marina) have the ability to elongate 18:2n-6 (linoleic acid) to produce 20:2n-6, which through a desaturation pathway can yield de novo 20:4n-6 (Olive et al. 2009). In addition, polychaetes can also retain most 20:4n-6 (AA) present in their diet $(\mathrm{OM}=$ $\left.0.12 \pm 0.02 \mu \mathrm{g} \mathrm{g}^{-1} \mathrm{DW}\right)$. AA is an essential FA in fish nutrition, particularly during early life phases (e.g. larval stages), thus being paramount when selecting ingredients to fulfil the nutritional needs of cultured marine fish (Bell \& Sargent 2003). According to other studies, palmitic acid (16:0) represents one of the most abundant saturated FAs present in polychaetes (García-Alonso et al. 2008, Brown et al. 2011, Techaprempreecha et al. 2011, Santos et al. 2016). Palmitic acid is the first FA to be biosynthesized and is a precursor of longer-chain saturated FA (Nelson \& Cox 2004). Palmitic acid is also a precursor of many types of molecules with physiological relevance, such as membrane lipids, fats and waxes (García-Alonso et al. 2008).

Results show that the proposed system for culturing $H$. diversicolor enables the recovery of HUFAs (e.g. EPA, DHA and AA) and palmitic acid into the tissues of these polychaetes. These FA can be reintroduced into productive systems through the potential of $H$. diversicolor to recycle these key ingredients available in different food sources originating from cultivated fish (POM, OM, FEED A and B). Without the action of $H$. diversicolor, these essential FA would likely be lost into the environment.

In its natural habitat, $H$. diversicolor is prey for higher trophic levels, either small fish such as the common goby Pomatoschistus microps and the sand goby P. minutus (Scaps 2002), or larger fish also used for human consumption, such as the Senegalese sole Solea senegalensis (Rosa et al. 2008). This may somehow explain the high level of acceptability displayed by this prey when offered to farmed fish species. In the present study, it was shown that cultivated $H$. diversicolor displays a FA profile that holds great potential to marine fish aquaculture as: (1) it is able to reduce the loss of essential FA from the productive system to the environment; and (2) it displays an enhanced nutritional value when compared to wild 
specimens (e.g. the presence of DHA in its FA profile). Moreover, the average number of LPC recorded in the present study after $5 \mathrm{mo}$ is the equivalent of approximately 100 bait packages identical to those initially used to stock each tank (with circa 70 specimens per package).

\section{CONCLUSIONS}

Overall, the present study confirms the potential of Hediste diversicolor for the bioremediation of superintensive marine fish farm effluents and highlights its ability to retain high value nutrients (e.g. HUFA in general and EPA in particular, and to a lesser extent DHA) from fish feeds that would otherwise be lost from the production environment. Ragworm biomass of large specimens may be valued selectively if traded live for sport fish bait, as these are traded at a unitary level (pack of live bait) and not per kg. LPC can also be frozen and traded for maturation diets for fish and/or shrimp broodstock, with their higher level of DHA being used as a feature that may grant them a premium market value over wild conspecifics. The biomass of small, medium or large cultured polychaetes (SPC, MPC and LPC, respectively) may be valued as a whole through their use as a premium ingredient for finishing diets of farmed marine organisms, thus overcoming the need to grade cultured ragworms.

Acknowledgements. This research was supported by the PROMAR-European Fisheries Fund through the STEP project, coordinated by Aquacria Piscícolas SA (Sea8 Company) and by FCT (Portuguese Foundation for Science and Technology) through a PhD grant awarded to B.M. (SFRH/BD/ 96037/2013) and a postdoctoral grant awarded to C.N. (SFRH/BPD/100627/2014). This work was also supported by the Integrated Programme of SR\&TD 'Smart Valorization of Endogenous Marine Biological Resources Under a Changing Climate' (Centro-01-0145-FEDER-000018), co-funded by the Centro 2020 program, Portugal 2020, European Union, through the European Regional Development Fund. Thanks are also due, for financial support, to CESAM (UID/AMB/50017/2013) and QOPNA (FCT UID/QUI/00062/ 2013), to FCT/MEC through national funds, and to FEDER for the co-funding within the PT2020 Partnership Agreement and Compete 2020. The authors also thank all colleagues who helped with the field work.

\section{LITERATURE CITED}

Aberson MJR, Bolam SG, Hughes RG (2011) The dispersal and colonisation behaviour of the marine polychaete Nereis diversicolor (O. F. Müller) in south-east England. Hydrobiologia 672:3-14
Aberson MJ, Bolam SG, Hughes RG (2016) The effect of sewage pollution on the feeding behaviour and diet of Hediste (Nereis diversicolor (O.F. Müller, 1776)) in three estuaries in south-east England, with implications for saltmarsh erosion. Mar Pollut Bull 105:150-160

Alexander KA, Potts TP, Freeman S, Israel D and others (2015) The implications of aquaculture policy and regulation for the development of integrated multi-trophic aquaculture in Europe. Aquaculture 443:16-23

Anderson MJ (2008) Animal-sediment relationships re-visited: characterising species' distributions along an environmental gradient using canonical analysis and quantile regression splines. J Exp Mar Biol Ecol 366:16-27

Aued-Pimentel S, Lago JHG, Chaves MH, Kumagai EE (2004) Evaluation of a methylation procedure to determine cyclopropenoid fatty acids from Sterculia striata St. Hil. Et Nauds seed oil. J Chromatogr A 1054:235-239

Barrington K, Chopin T, Robinson S (2009) Integrated multitrophic aquaculture (IMTA) in marine temperate waters. In: Soto D (ed) Integrated mariculture: a global review. FAO Fish Aquacult Tech Pap 529. FAO, Rome, p 7-46

Bell JG, Sargent JR (2003) Arachidonic acid in aquaculture feeds: current status and future opportunities. Aquaculture 218:491-499

Bischoff AA, Fink P, Waller U (2009) The fatty acid composition of Nereis diversicolor cultured in an integrated recirculated system: possible implications for aquaculture. Aquaculture 296:271-276

Breton S, Dufresne F, Desrosiers G, Blier PU (2003) Population structure of two northern hemisphere polychaetes, Neanthes virens and Hediste diversicolor (Nereididae), with different life-history traits. Mar Biol 142:707-715

Brown N, Eddy S, Plaud S (2011) Utilization of waste from a marine recirculating fish culture system as a feed source for the polychaete worm, Nereis virens. Aquaculture 322-323:177-183

Chopin T, Robinson SMC, Troell M, Neori A, Buschmann AH, Fang J (2008) Multitrophic integration for sustainable marine aquaculture. In: Jørgensen SE, Fath BD (eds) Ecological engineering. Encyclopedia of ecology, Vol. 3. Elsevier, Oxford, p 2463-2475

Clarke K, Gorley R (2006) PRIMER v6: User manual/tutorial. PRIMER-E, Plymouth

Fang J, Jiang Z, Jansen H, Hu F and others (2017) Applicability of Perinereis aibuhitensis Grube for fish waste removal from fish cages in Sanggou Bay, PR China. J Ocean Univ China 16:294-304

Fidalgo e Costa P, Narciso L, da Fonseca LC (2000) Growth, survival and fatty acid profile of Nereis diversicolor (O.F. Müller, 1776) fed on six different diets. Bull Mar Sci 67: 337-344

Fritzsche D, von Oertzen JA (1995) Metabolic responses to changing environmental conditions in the brackish water polychaetes Marenzelleria viridis and Hediste diversicolor. Mar Biol 121:693-699

* García-Alonso J, Müller CT, Hardege JD (2008) Influence of food regimes and seasonality on fatty acid composition in the ragworm. Aquat Biol 4:7-13

Hutchinson W, Jeffrey M, O'Sullivan D, Casement D, Clarke S (2004) Recirculating aquaculture systems minimum standards for design, construction and management. RAS MSDCM V2 040220. Inland Aquaculture Association of South Australia, Kent Town

Lillebø AI, Cleary DFR, Marques B, Reis A, Silva TL, Calado R (2012) Ragworm fatty acid profiles reveals habitat and 
trophic interactions with halophytes and with mercury. Mar Pollut Bull 64:2528-2534

Luis OJ, Passos AM (1995) Seasonal changes in lipid content and composition of the polychaete Nereis (Hediste) diversicolor. Comp Biochem Physiol 111:579-586

Marques B, Calado R, Lillebø AI (2017) New species for the biomitigation of a super-intensive marine fish farm effluent: combined use of polychaete-assisted sand filters and halophyte aquaponics. Sci Total Environ 599-600: 1922-1928

Martins CIM, Eding EH, Verdegem MCJ, Heinsbroek LTN and others (2010) New developments in recirculating aquaculture systems in Europe: a perspective on environmental sustainability. Aquacult Eng 43:83-93

Murray F, Solan M, Douglas A (2017) Effects of algal enrichment and salinity on sediment particle reworking activity and associated nutrient generation mediated by the intertidal polychaete Hediste diversicolor. J Exp Mar Biol Ecol 495:75-82

Nelson DL, Cox MM (2004) Lehninger principles of biochemistry, 4th edn. W H Freeman \& Co, New York, NY

Nesto N, Simonini R, Prevedelli D, Da Ros L (2012) Effects of diet and density on growth, survival and gametogenesis of Hediste diversicolor (O.F. Müller, 1776) (Nereididae, Polychaeta). Aquaculture 362-363:1-9

Olive PJW (1999) Polychaete aquaculture and polychaete science: a mutual synergism. Hydrobiologia 402:175-183

Olive PJW, Duangchinda T, Ashforth E, Craig S, Ward AC, Davies SJ (2009) Net gain of long-chain polyunsaturated fatty acids (PUFA) in a lugworm Arenicola marina bioturbated mesocosm. Mar Ecol Prog Ser 387:223-239

Palmer PJ (2010) Polychaete-assisted sand filter. Aquaculture 306:369-377

Rosa S, Granadeiro JP, Vinagre C, França S, Cabral HN, Palmeirim JM (2008) Impact of predation on the polychaete Hediste diversicolor in estuarine intertidal flats. Estuar Coast Shelf Sci 78:655-664

Santos A, Granada L, Baptista T, Anjos C and others (2016) Effect of three diets on the growth and fatty acid profile of the common ragworm Hediste diversicolor (O.F. Müller, 1776). Aquaculture 465:37-42

Scaps P (2002) A review of the biology, ecology and potential use of the common ragworm Hediste diversicolor $(\mathrm{O}$. F. Müller) (Annelida: Polychaeta). Hydrobiologia 470: 203-218

Schneider O, Sereti V, Eding EH, Verreth JAJ (2005) Analysis of nutrient flows in integrated intensive aquaculture systems. Aquacult Eng 32:379-4011

Smith RI (1964) On the early development of Nereis diversicolor indifferent salinities. J Morphol 114:437-463

Techaprempreecha S, Khongchareonporn N, Chaicharoenpong C, Aranyakananda P, Chunhabundit S, Petsom A (2011) Nutritional composition of farmed and wild sandworms, Perinereis nuntia. Anim Feed Sci Technol 169: 265-269

van Rijn J, Tal Y, Schreier HJ (2006) Denitrification in recirculating systems: Theory and applications. Aquacult Eng 34:364-376

Würzberg L, Peters J, Schüller M, Brandt A (2011) Diet insights of deep-sea polychaetes derived from fatty acid analyses. Deep Sea Res Part II 58:153-162

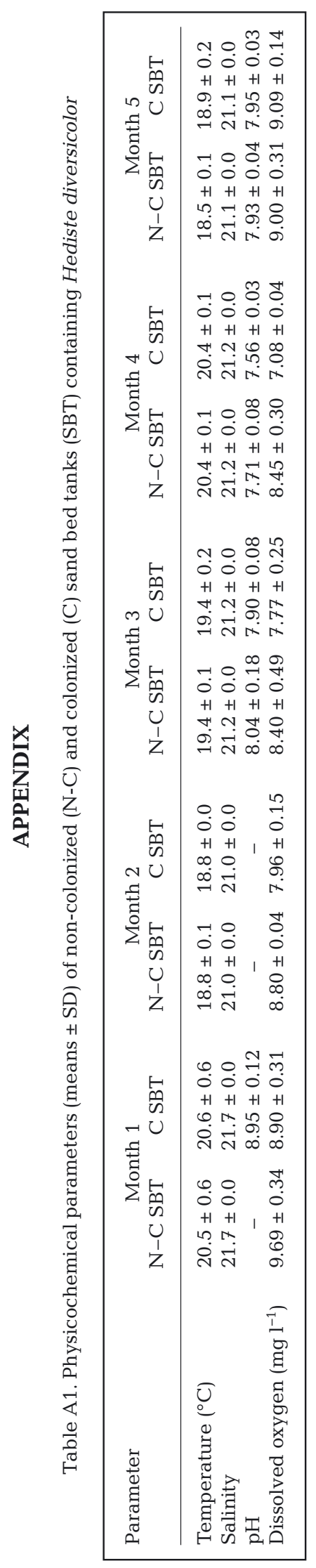

